\title{
Detection of Gaeumannomyces graminis Varieties Using Polymerase Chain Reaction with Variety-Specific Primers
}

\author{
H. M. Fouly and H. T. Wilkinson, Department of Natural Resources and Environmental Sciences, University of \\ Illinois at Urbana-Champaign, Urbana 61801
}

\begin{abstract}
Fouly, H. M., and Wilkinson, H. T. 2000. Detection of Gaeumannomyces graminis varieties using polymerase chain reaction with variety-specific primers. Plant Dis. 84:947-951.

The polymerase chain reaction (PCR) was used for detection of Gaeumannomyces graminis, the causal agent of take-all disease in wheat, oats, and turfgrass. NS5 and NS6 universal primers amplified the middle region of $18 \mathrm{~S}$ ribosomal DNA of Gaeumannomyces species and varieties. Primers GGT-RP (5' TGCAATGGCTTCGTGAA $3^{\prime}$ ) and GGA-RP (5' TTTGTGTGTGAC CATAC $3^{\prime}$ ) were developed by sequence analysis of cloned NS5-NS6 fragments. The primer pair NS5:GGT-RP amplified a single 410-bp fragment from isolates of G. graminis var. tritici, a single 300-bp fragment from isolates of G. graminis var. avenae, and no amplification products from isolates of G. graminis var. graminis or other species of Gaeumannomyces. The primer pair NS5:GGA-RP amplified a single 400-bp fragment from isolates of varieties tritici and avenae. Two sets of primer pairs (NS5:GGT-RP and NS5:GGA-RP) were used in PCR reactions to detect and identify the varieties tritici and avenae either colonizing wheat, oats, or grass roots, or in culture. No amplification products were observed using DNA extracted from plants infected with eight other soilborne fungal pathogens or from uninoculated plants.
\end{abstract}

Gaeumannomyces graminis (Sacc.) Arx $\&$ D. Olivier, a filamentous soilborne fungus, parasitizes the roots and crowns of susceptible members of the Gramineae $(23,25)$. Gaeumannomyces graminis var. tritici J. Walker is the etiologic agent of wheat (Triticum aestivum L.) and barley (Hordeum vulgare L.) take-all disease, a major root disease that limits yield in many areas of the world $(25,26)$. Gaeumannomyces graminis var. avenae (E.M. Turner) Dennis can cause take-all of oats (Avena sativa L.) and take-all patch of bentgrass (Agrostis palustris Huds.), and occasionally is isolated from barley and wheat. Gaeumannomyces graminis var. graminis infects and colonizes wheat, but in contrast to varieties tritici or avenae, it causes little take-all. However, G. graminis var. graminis causes Bermudagrass (Cynodon dactylon (L.) Pers.) decline (5), spring dead spot (15), take-all root rot of St. Augustinegrass (Stenotaphrum secundatum (Walt.) Kuntze) $(6,13,31)$, crown sheath rot of rice (Oryza sativa L.) (26), root rot of centipedegrass (Eremochloa ophiuroides (Munro) Hack.) (28), and root rot of zoysiagrass (Zoysia japonica Steudel) (30).

Diagnosis of take-all disease is generally based on visual symptoms, host identi-

Corresponding author: H. T. Wilkinson

E-mail: HWilkins@uiuc.edu

Accepted for publication 19 April 2000.

Publication no. D-2000-0627-01R

(C) 2000 The American Phytopathological Society fication, predisposing environmental conditions, and the presence of darkly pigmented, ectotrophic runner hyphae on plant roots and/or crowns. Identification of $G$. graminis as the possible etiological agent in diseased plants generally is attempted by culturing the isolated fungus in vitro, and then observing both the colony morphology and the teleomorphic state. The formation of perithecia in field-infected plants is rare, and in vivo formation of this teleomorph usually occurs in about half of the isolates cultured.

The polymerase chain reaction (PCR) assay is highly sensitive and reproducible as a tool for detection and identification of fungi when species-specific primers are carefully designed. This approach has been used to identify fungi, including Fusarium spp. (22), G. graminis (10), Rhizoctonia oryzae Ryker \& Gooch (14), Magnaporthe poae Landschoot \& Jackson (3), Leptosphaeria korrae J.C. Walker \& A.M. Sm. (24), Ophiosphaerella herpotricha (Fr.:Fr.) J.C. Walker (24), Phialophora gregata (Allington \& D.W. Chamberlain) W. Gams (4), and Verticillium spp. (16,18). Nuclear rDNA of fungi consists of the small and large subunits, a $5.8 \mathrm{~S}$ region, and the internal transcribed spacer (ITS) region(s). Each subunit and region base sequence is variable among the genera and species of fungi (1). The ITS region of Gaeumannomyces is highly variable among its species (8) and less variable among its varieties (2). However, the small subunit of nuclear rDNA is distinctly variable among the varieties of $G$. graminis (8). The copy number of the rDNA repeat is more than
50 per genome, suggesting a possible high sensitivity for detection if used as a target gene for PCR. Thus, the small subunit of nuclear rDNA would be valuable for detection of G. graminis varieties using PCR amplification. In previous studies with $G$. graminis, oligonucleotide primer pairs were derived from clone pMSU315 of $G$. graminis (21) and from direct sequencing of the ITS region of $G$. graminis var. tritici and G. graminis var. avenae (2). These primer pairs amplified multiple-sized DNA fragments in $G$. graminis varieties, but $G$. graminis var. graminis could not be differentiated from other $G$. graminis varieties (tritici and avenae). In a previous report (8), we showed that the middle region (NS5-NS6 fragment) of the small subunit of nuclear rDNA was variable in size among the species and varieties of $G$. graminis. The objective of our research was to develop variety-specific primers from the middle region of the small subunit of nuclear rDNA (18S rDNA) for the identification and differentiation of G. graminis varieties infecting plant tissue.

\section{MATERIALS AND METHODS}

Fungal isolates and DNA extraction. Isolates of $G$. graminis var. tritici, $G$. graminis var. graminis, $G$. graminis var. avenae, G. incrustans, G. cylindrosporus, and $G$. leptosporus used in this study are listed in Table 1. Cultures were maintained on one-fifth strength potato dextrose agar (PDA) (29) plates. To obtain mycelia for DNA extraction, the isolates were grown in GYP medium (glucose $2 \%$, yeast extract $0.5 \%$, and peptone $0.5 \%$ ) (9), filtered, and ground in liquid nitrogen using a mortar and pestle. DNA was extracted according to the methods used by Murray and Thompson (17).

PCR. Primers NS5 and NS6 (27) were used to amplify part of the small subunit of nuclear rDNA (18S rDNA). Primers were synthesized at the Genetic Engineering Facility of the Biotechnology Center at the University of Illinois at Urbana-Champaign. Amplification reactions were made in a total volume of $50 \mu \mathrm{l}$ containing: 10 $\mathrm{mM}$ Tris- $\mathrm{HCl}(\mathrm{pH} \mathrm{8.3)} ; 50 \mathrm{mM} \mathrm{KCl} ; 2.0$ $\mathrm{mM} \mathrm{MgCl} 2 ; 200 \mu \mathrm{M}$ each of dATP, dCTP, dGTP, and dTTP; $0.4 \mu \mathrm{M}$ each of the primers; $50 \mathrm{ng}$ of genomic DNA; and 1.0 unit of Taq DNA polymerase (Promega Corporation, Madison, WI), under $60 \mu \mathrm{l}$ of mineral oil (Sigma Chemical Co., St. Louis, MO). Negative controls, in which 
the genomic DNA template was replaced by water, were used in all experiments to test for contamination. Temperature cycling was carried out in a DNA thermal cycler (Gene Amp PCR 2400; Perkin-Elmer Cetus, Foster, CA). An initial denaturation step of $93^{\circ} \mathrm{C}$ for $3 \mathrm{~min}$ was followed by 35 amplification cycles of denaturation, annealing, and extension. Temperatures and times for these steps were $93^{\circ} \mathrm{C}$ for 1 $\min , 52^{\circ} \mathrm{C}$ for $1 \mathrm{~min}$, and $72^{\circ} \mathrm{C}$ for $1 \mathrm{~min}$, respectively. After 35 cycles were completed, the samples were incubated at $72^{\circ} \mathrm{C}$ for $5 \mathrm{~min}$. Ten $\mu \mathrm{l}$ of the amplification products were separated by electrophoresis in $1.4 \%$ agarose gels, stained with ethidium bromide, and photographed under UV light. All assays were performed at least two times.

DNA sequencing and analysis. PCR products (called N5-N6 fragments) were purified using a QIAquick DNA purification kit (QIAGEN Inc., Valencia, CA). The purified N5-N6 fragments from isolates WF9039, WF9040 (G. graminis var. tritici); WF922, WF937 (G. graminis var. avenae); WF921, WF9238 (G. graminis var. graminis); WF914 (G. incrustans); WF912 (G. cylindrosporus); and WF9427 (G. leptosporus) were cloned using a TA Cloning Kit and pCRII vector (Invitrogen Corporation, Carlsbad, CA). PCR amplified products were sequenced using an $\mathrm{ABI}$ automated sequencer with fluorescent-dyelabeled dideoxy terminators at the Genetic Engineering Facility of the Biotechnology Center at the University of Illinois at Urbana-Champaign.

Selection and specificity of $G$. graminis var. tritici- and G. graminis var. avenae-specific primers. The DNA sequences were edited by SeqEd version 1.0.3 (Applied Biosystems Division, Foster, CA). Sequence alignments were done with the CLUSTAL V program (11). Two PCR reverse primers, GGT-RP and GGA$\mathrm{RP}$, were designed specifically for varieties tritici and avenae of $G$. graminis based on the sequence of the N5-N6 region of 18S rDNA. The design of the primers was aided by use of the software OLIGO, version 4.1 (National Bioscience, Plymouth, $\mathrm{MN})$. Primer NS5 was used with each of the reverse primers (GGT-RP and GGA$\mathrm{RP})$ to assess their specificity among samples of $G$. graminis var. tritici and $G$. graminis var. avenae. PCR amplifications were conducted with DNA preparations from Gaeumannomyces from various sources (Table 1) and from other genera of fungi including: Colletotrichum graminicola (Ces.) Wilson, Fusarium solani (Mart.) Sacc., F. graminearum Schwabe, Leptosphaeria korrae, Magnaporthe poae, Phialophora sp., Pythium ultimum Trow, Rhizoctonia solani Kühn, Sclerotinia homoeocarpa F.T. Bennett, and Trichoderma viride Pers.:Fr.

Detection and identification of $G$. graminis var. tritici or G. graminis var.
Table 1. Isolates of Gaeumannomyces species and varieties used to screen the polymerase chain reaction primers (NS5:GGT-RP and NS5:GGA-RP)

\begin{tabular}{|c|c|c|c|c|}
\hline \multirow{2}{*}{$\begin{array}{c}\text { Species } \\
\text { Isolate }\end{array}$} & \multirow[b]{2}{*}{ Host } & \multirow{2}{*}{$\begin{array}{c}\text { Source } \\
\text { (collector/state) }\end{array}$} & \multicolumn{2}{|c|}{ Primer } \\
\hline & & & GGT-RPa & GGA-RPb \\
\hline
\end{tabular}

G. graminis var. tritici

WF861

WF9036 (GH7)

WF9037 (RL-4)

WF9039 (GH-90)

WF9040 (P-L)

WF9041 (STV-1)

WF9419

WF9420 (Jo-1)

WF9421 (RL-287)

WF9422

WF9423 (TA-85)

WF964 (550)

WF965 (528)

WF966 (558)

WF967 (568)

WF968 (698)

WF969 (801)

WF9610 (802)

WF9611 (804)

WF9634 (GGT-8)

WF9635 (GGT-11)

WF9637 (GGT-12)

G. graminis var. avenae

WF9022

WF9024

WF9025

WF9026

WF9032

WF922

WF934

WF936

WF937 (93BRWI)

WF939 (93RHF)

WF9310 (93-SOA)

WF9311 (RL1)

WF9312 (93GLK18G)

WF9424 (255)

WF9426 (260)

WF9445 (POCO-4)

WF9448

WF9449 (FR- 1)

WF951 (OV-2)

WF953 (NETC75)

G. graminis var. graminis

WF9014

WF9236 (FL-177)

WF9237 (FL-167)

WF9238 (FL- 199)

WF9450

WF9451

WF9452 (FL-173)

WF9454 (FL-195)

WF9455 (FL-198)

WF9457 (FL-208)

WF9458

WF9462 (FL-221)

WF9463

WF9469 (92-8186-2B)

WF9470 (TX-9 I - 1)

WF9471 (PPRI-4754)

WF9472

G. incrustans

WF867

WF914

WF9341

WF9342
Wheat

Wheat

Wheat

Wheat

Wheat

Wheat

Wheat

Wheat

Wheat

Wheat

Wheat

Wheat

Wheat

Wheat

Wheat

Wheat

Wheat

Wheat

Wheat

Wheat

Wheat

Wheat

Bentgrass

Bentgrass

Bentgrass

Bentgrass

Bentgrass

Bentgrass

Bentgrass

Bentgrass

Bentgrass

Bentgrass

Bentgrass

Bentgrass

Bentgrass

Bentgrass

Bentgrass

Bentgrass

Bentgrass

Bentgrass

Bentgrass

Bentgrass

Zoysiagrass

St. Augustine

Bermudagrass

St. Augustine

Bermudagrass

Bermudagrass Rice

St. Augustine

St. Augustine

Bermudagrass

Bermudgrass

Rice

St. Augustine

Rice

Rice

Millet

Soybean

Zoysiagrass

Zoysiagrass

St. Augustine

Bermudagrass
Bockus/KS

Bockus/KS

Bockus/KS

Bockus/KS

Bockus/KS

Bockus/KS

Bockus/KS

Bockus/KS

Bockus/KS

Bockus/KS

Mathre/MT

Mathre/MT

Mathre/MT

Mathre/MT

Mathre/MT

Mathre/MT

Mathre/MT

Mathre/MT

Huber/IN

Huber/IN

Huber/IN

Wilkinson/IL

Wilkinson/IL

Wilkinson/IL

Wilkinson/IL

Wilkinson/IL

Jackson/RI

Wilkinson/France

Wilkinson/IL

Wilkinson/WI

Wilkinson/IL

Wilkinson/IL

Wilkinson/IL

Wilkinson/IL

Wilkinson/WA

Wilkinson/WA

Sanders/PA

Sanders/PA

Wilkinson/France

Wilkinson/IL

Wilkinson/IL

Wilkinson/IL

Elliott/FL

Elliott/FL

Elliott/FL

Wilkinson/FL

Wilkinson/FL

Elliott/FL

Elliott/FL

Elliott/FL

Elliott /FL

Wilkinson/FL Elliott/FL

Wilkinson/CA

Elliott/AR

Elliott/TX

South Africa

Australia

Wilkinson/MO

Wilkinson/KS

Wilkinson/FL

Wilkinson/FL
Bockus/KS

$\begin{array}{ll}+ & + \\ + & + \\ + & + \\ + & + \\ + & + \\ + & + \\ + & + \\ + & + \\ + & + \\ + & + \\ + & + \\ + & + \\ + & + \\ + & + \\ + & + \\ + & + \\ + & + \\ + & + \\ + & + \\ + & + \\ + & + \\ + & +\end{array}$

\footnotetext{
${ }^{a}$ A single 410-bp product was amplified from G. graminis var. tritici isolates and a single 300-bp product was amplified from $G$. graminis var. avenae isolates.

b A single 400-bp product was amplified from isolates of G. graminis varieties tritici and
} avenae. 
Table 1. (continued)

\begin{tabular}{|c|c|c|c|c|}
\hline \multirow{2}{*}{$\begin{array}{l}\text { Species } \\
\text { Isolate }\end{array}$} & \multirow[b]{2}{*}{ Host } & \multirow{2}{*}{$\begin{array}{c}\text { Source } \\
\text { (collector/state) }\end{array}$} & \multicolumn{2}{|c|}{ Primer } \\
\hline & & & GGT-RPa & GGA-RPb \\
\hline \multicolumn{5}{|c|}{ G. incrustans (continued) } \\
\hline WF9343 & Bermudagrass & Wilkinson/FL & - & - \\
\hline WF9344 & Bermudagrass & Wilkinson/FL & - & - \\
\hline WF9416 & Zoysiagrass & Wilkinson/KS & - & - \\
\hline WF9417 & Zoysiagrass & Wilkinson/KS & - & - \\
\hline WF9418 & Zoysiagrass & Wilkinson/KS & - & - \\
\hline WF9446 & Annual bluegrass & Jackson/RI & - & - \\
\hline WF9447 & Annual bluegrass & Wilkinson/NY & - & - \\
\hline \multicolumn{5}{|c|}{ G. cylindrosporus } \\
\hline WF912 & Wheat & Wilkinson/KS & - & - \\
\hline \multicolumn{5}{|c|}{ G. leptosporus } \\
\hline WF9427 & & (ATCC24161) & - & - \\
\hline \multicolumn{5}{|c|}{ G. graminis-like isolates } \\
\hline WF9023 & bentgrass & Wilkinson/IL & + & + \\
\hline WF9024 & Bentgrass & Wilkinson/IL & + & + \\
\hline WF9033 & Bentgrass & Wilkinson/IL & + & + \\
\hline WF9124 & St. Augustine & Wilkinson/CA & - & - \\
\hline WF9250 & Wheat & Fouly/Egypt & - & - \\
\hline WF932 & Zoysiagrass & Wilkinson/IL & - & - \\
\hline WF933 & Bentgrass & Wilkinson/France & + & + \\
\hline WF935 & Bentgrass & Wilkinson/IL & + & + \\
\hline WF938 & Bentgrass & Wilkinson/IL & + & + \\
\hline WF9435 & Bermudagrass & Wilkinson/GA & - & - \\
\hline WF9232 & Bermudagrass & Elliott/FL & - & - \\
\hline WF9465 & Bermudagrass & Elliott/FL & - & - \\
\hline WF9467 & Bermudagrass & Elliott/FL & - & - \\
\hline WF9468 & Bermudagrass & Elliott/FL & - & - \\
\hline WF9453 & Bermudagrass & Elliott/FL & - & - \\
\hline WF9456 & Bermudagrass & Elliott/FL & - & - \\
\hline WF9459 & Bermudagrass & Elliott/FL & - & - \\
\hline WF9460 & Bermudagrass & Elliott/FL & - & - \\
\hline WF9461 & Bermudagrass & Elliott/FL & - & - \\
\hline WF9464 & Bermudagrass & Elliott/FL & - & - \\
\hline WF9432 & Centipedegrass & Wilkinson/GA & - & - \\
\hline
\end{tabular}

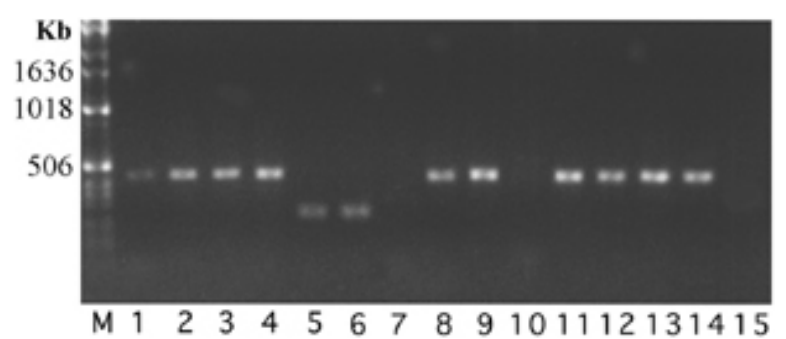

Fig. 1. Specific detection of Gaeumannomyces graminis var. tritici and G. graminis var. avenae isolates using polymerase chain reaction (PCR) with NS5:GGT-RP primer pair (lanes 1 to 7) and with NS5: GGA-RP primer pair (lanes 8 to 15). Lane M, $1 \mathrm{~kb}$ DNA ladder; lanes 1 to 4, 11, and 12 are $G$. graminis var. tritici isolates WF9039, WF9040, WF9419, WF9421, WF964, and WF969, respectively; lanes 5, 6, 8, 9, 13, and 14 are G. graminis var. avenae isolates WF9024, WF9026, WF922, WF934, WF936, and WF937, respectively; and lanes 7, 10, and 15 are G. graminis var. graminis isolates WF9014, WF9236, and WF9238, respectively.

avenae infecting wheat, oats, and turfgrass roots. Both field-infected and inoculated wheat, oats, and bentgrass plants were used as potential sources of Gaeumannomyces. Plants were established in Cone-tainers (Ray Leach "Cone-tainers"; Stuewe \& Sons, Inc., Corvallis, OR) using sterilized seed according to Wilkinson et al. (29). One $0.5 \mathrm{~cm}^{2}$ piece of fungal culture grown on one-fifth PDA was placed on top of the vermiculite and covered with additional vermiculite prior to seeding. Each Cone-tainer received $10 \mathrm{ml}$ of sterile distilled water and was incubated fected and infected roots were immediately frozen to $-80^{\circ} \mathrm{C}$. All field-infected plants displayed take-all symptoms and were collected in Illinois, Wisconsin, Kansas, Oregon, and Washington. Field infected plants were stored at $-80^{\circ} \mathrm{C}$.

DNA was extracted from plants by grinding root tissue (about $0.1 \mathrm{~g}$ ) in liquid nitrogen and using a DNA extraction kit (QIAGEN). The extracted DNA was used in PCR assays with primer pairs NS5:GGT-RP or NS5:GGA-RP. PCR reactions and conditions for detecting $G$. graminis var. tritici and $G$. graminis var. avenae in plants were the same as described above. All experiments (except DNA isolations and sequencing reactions) were performed at least twice.

\section{RESULTS}

DNA sequences and design of $G$. graminis var. tritici- and $G$. graminis var. avenae-specific primers. The PCR assay with primers NS5 and NS6 amplified fragments from 280 to $1,100 \mathrm{bp}$ for Gaeumannomyces species and varieties. Isolates of G. graminis var. tritici and G. graminis var. avenae had unique fragments of 627 and $607 \mathrm{bp}$, respectively. The nucleotide sequences of these two amplified fragments were similar, except for a 23-bp insertion in the amplified fragment of $G$. graminis var. tritici isolates. The insertion was located at base 384, downstream from the NS5 primer sequence. After multiple sequence alignment analysis of the N5-N6 fragments, the GGT- and GGA-specific primers that were used with the NS5 forward primer were designed with the following sequences: GGT-RP (5' TGCAAT GGCTTCGTGAA 3') and GGA-RP (5' TTTGTGTGTGACCATAC 3'). The primer GGT-RP was selected from the 23-bp insertion sequence of $G$. graminis var. tritici isolates that was not present in $G$. graminis var. avenae isolates. The primer GGA-RP was selected from nucleotide sequences in G. graminis var. avenae isolates that had no homology with those of $G$. graminis var. tritici isolates and was located at base 367 , downstream from the NS5 primer sequence.

Specificity of the primers GGT-RP and GGA-RP. A 410-bp fragment from isolates of G. graminis var. tritici and a 300-bp fragment from isolates of $G$. graminis var. avenae were amplified using the NS5 and GGT-RP primers. No fragments were amplified from purified DNA of G. graminis var. graminis isolates (Figs. 1 and 2A). Only a 400-bp fragment was amplified from isolates of $G$. graminis var. tritici and $G$. graminis var. avenae using the NS5 and GGA-RP primers (Figs. 1 and 2A). No fragments were amplified using the primer pairs NS5:GGT-RP or NS5:GGA-RP from purified DNA of the other Gaeumannomyces species tested (Fig. 2A) nor from any of the other 10 fungi tested (Fig. 2B). 


\section{A}

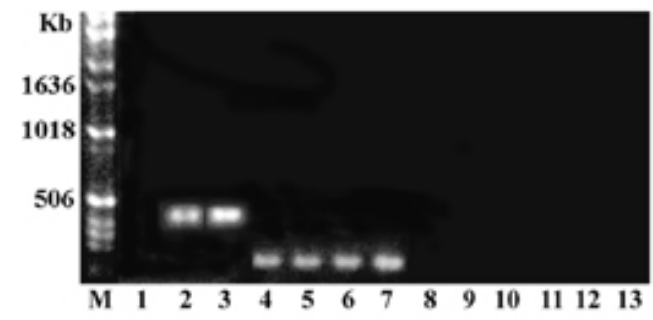

B

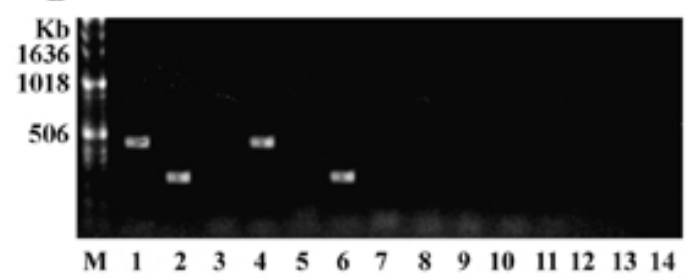

Fig. 2. Amplification of purified genomic DNA from different isolates of Gaeumannomyces species and varieties and other fungal species by polymerase chain reaction (PCR) with primers NS5:GGT-RP. (A) Lane M, 1 kb DNA ladder; lane 1, no DNA template; lanes 2 and 3, G. graminis var. tritici isolates WF965 and WF9610, respectively; lanes 4 to 7, G. graminis var. avenae isolates WF936, WF939, WF9312, and WF9424, respectively; lanes 8 and 9, G. graminis var. graminis isolates WF9236 and WF9450, respectively; lanes 10 and 11, G. incrustans isolates WF914 and WF867, respectively; lane 12, G. cylindrosporus isolate WF912; lane 13, G. leptosporus isolate WF9427. (B) Lane M, $1 \mathrm{~kb}$ DNA ladder; lane 1, G. graminis var. tritici isolate WF969; lane 2, G. graminis var. avenae isolate WF9311; lane 3, G. graminis var. graminis isolate WF9451; lane 4, G. graminis var. tritici isolate WF9423; lane 5, G. graminis var. graminis isolate WF9455; lane 6, G. graminis var. avenae isolate WF9426; lane 7, Sclerotinia homoeocarpa isolate WF946; lanes 8 and 9, Magnaporthe poae isolates WF9119 and WF841, respectively; lane 10, Fusarium solani; lane 11, F. graminearum; lane 12, Colletotrichum graminicola; lane 13, Rhizoctonia solani isolate WF9222; and lane 14, Trichoderma viride.

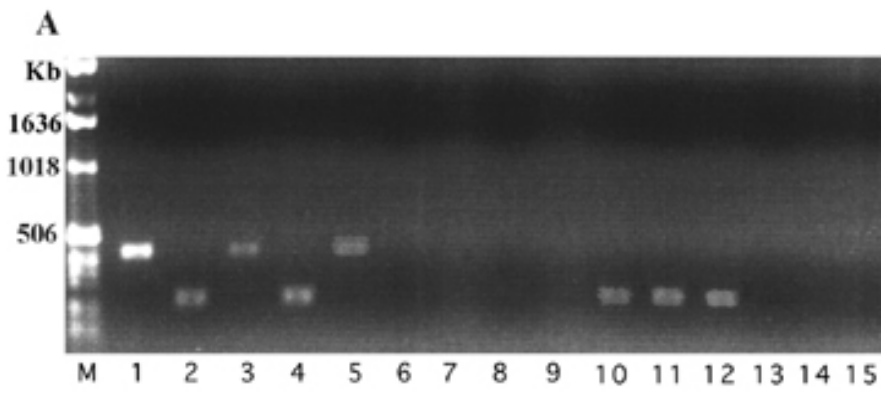

B

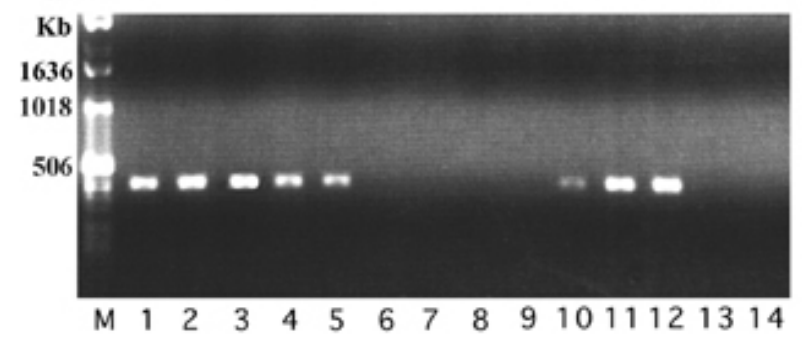

Fig. 3. (A) Polymerase chain reaction (PCR) amplification of DNA from plant tissue with primers NS5 and GGT-RP. Lane M, 1 kb DNA ladder; lanes 1, 3, and 5, wheat roots infected with G. graminis var. tritici isolates WF9039, WF9040, and WF9041, respectively; lanes 2 and 4, oat and bentgrass roots inoculated with G. graminis var. avenae isolates WF922 and WF937, respectively; lanes 10, 11, and 12, bentgrass roots naturally infected with $G$. graminis var. avenae; lanes 6 to 9, and 13 to 15 , bentgrass roots inoculated with G. graminis var. graminis isolate WF9238, Magnaporthe poae isolate WF9119, Phialophora sp., Sclerotinia homoeocarpa isolate WF946, Leptosphaeria korrae isolate WF9674, Rhizoctonia solani isolate WF9222, and Pythium ultimum, respectively. (B) PCR amplification of DNA from plant tissue with primers NS5 and GGA-RP. Lane M, $1 \mathrm{~kb}$ DNA ladder; lanes 1 and 2, wheat roots infected with G. graminis var. tritici isolates WF9039 and WF9040, respectively; lanes 3 and 4, oat roots inoculated with G. graminis var. avenae isolates WF922 and WF937, respectively; lane 5, bentgrass roots inoculated with $G$. graminis var. avenae isolate WF937; lanes 6 to 9, 13, and 14, bentgrass roots inoculated with G. graminis var. graminis isolate WF9238, M. poae isolate WF9119, Phialophora sp., S. homoeocarpa isolate WF946, L. korrae isolate WF9674, and $R$. solani isolate WF9222, respectively; lanes 10 to 12 , bentgrass roots naturally infected with $G$. graminis var. avenae.
Detection of $G$. graminis var. tritici and $G$. graminis var. avenae in infected wheat, oats, or turfgrass roots. $G$. graminis var. tritici and var. avenae were detected and identified from seedlings inoculated with these fungi. No amplification products were detected after PCR of DNA extracted from plants inoculated with G. graminis var. graminis, G. incrustans, G. cylindrosporus, G. leptosporus, $M$. poae, L. korrae, S. homoeocarpa, R. solani, $P$. ultimum, $F$. solani, $F$. graminearum, and Phialophora sp. The PCR assay with primer NS5 and either the GGTRP or GGA-RP primer amplified no DNA fragments from noninoculated plants, although the DNA did act as a template for primers NS5 and NS6. A 410-bp fragment was amplified repeatedly from DNA extracted from wheat infected with $G$. graminis var. tritici when the NS5 and GGT-RP primer pair was used (Fig. 3A). A 300-bp fragment was amplified from DNA extracted from oats and bentgrass infected with G. graminis var. avenae when this primer pair was used (Fig. 3A). No DNA sequences extracted from root tissue inoculated with G. graminis var. graminis, Phialophora sp., M. poae, L. korrae, S. homoeocarpa, R. solani, P. ultimum (Fig. 3A), G. incrustans, F. solani, or F. graminearum were amplified when the NS5 and GGT-RP primer pair was used. The presence of Gaeumannomyces species and varieties in inoculated plants was confirmed by culturing them on selective medium MS-7 (10) and comparing culture morphology to that of the original culture used as inoculum. Only a 400-bp fragment was amplified from DNA extracted from root tissue infected with $G$. graminis var. tritici or G. graminis var. avenae when the NS5 and GGA-RP primers were used (Fig. 3B). No DNA sequences extracted from root tissue inoculated with $G$. graminis var. graminis, Phialophora sp., M. poae, L. korrae, S. homoeocarpa, R. solani (Fig. 3B), P. ultimum, G. incrustans, F. solani, or $F$. graminearum were amplified by PCR using these primers.

\section{DISCUSSION}

A new and definitive system for identifying and separating $G$. graminis vars. tritici, avenae, and graminis has been developed. Further, using specific primers for PCR amplification, it is now possible to identify and delineate the G. graminis varieties from field-infected tissue or cultures. In addition, these two sets of primer pairs (NS5:GGT-RP and NS5:GGA-RP) show no homology with $G$. graminis var. graminis, other species of Gaeumannomyces, or other tested fungi that are known pathogens of cereals and turfgrass. We suggest that this simple procedure can be extended to the investigation of fungi that are known to infect other grass species (7). The primers were identified from the N5N6 region of $18 \mathrm{~S}$ rDNA. Ribosomal DNA 
(rDNA) provides a powerful tool for fungal identification and detection in plant tissue, because it is highly conserved and universally found in living cells (12). The ITS region was previously used to differentiate the species of Gaeumannomyces $(2,8)$. Because the ITS region is highly variable among species of Gaeumannomyces, it is a useful tool to differentiate these species (8). The ITS region is less variable among the varieties of $G$. graminis, thus precluding its use as a tool for differentiation (8). For Gaeumannomyces varieties, using larger rDNA fragments (18S [32] and 28S [19]) is more practical than using the ITS region. The development of techniques for rapid and easy sequencing of large stretches of $18 \mathrm{~S}$ and/or $28 \mathrm{~S}$ rDNA facilitated the exploitation of these fragments for evaluating phylogenetic relationships and developing specific primers for species and subspecies identification (20).

In this study the specific primers GGT$\mathrm{RP}$ and GGA-RP were used with the forward universal primer NS5 to (i) identify and differentiate isolates of $G$. graminis var. tritici, G. graminis var. avenae, and $G$. graminis var. graminis, and (ii) detect $G$. graminis var. tritici and $G$. graminis var. avenae infecting wheat, oats, or grasses.

This technique offers a major advantage over other published techniques. Bryan et al. (2) reported the development of a PCR assay and primers to detect $G$. graminis var. tritici and $G$. graminis var. avenae in artificially inoculated wheat and oats. The assay was tested on a small number of isolates, and the specificity of the primers was not established against $G$. graminis var. graminis, other soil fungi, or naturally infected plants. In addition, multiple-sized DNA fragments from $G$. graminis var. tritici were amplified using these primers (2). The reported use of nested primers for identifying G. graminis did not allow for differentiation among varieties (21).

The use of PCR to detect pathogens in plant tissue becomes more effective once inhibitors of PCR, which are contained in plant tissue, are removed $(4,10,24)$. To address the presence of substances inhibitory to PCR in host tissue, we tried three methods for the isolation of DNA from infected plant tissue. Two of the methods included grinding root tissue in liquid nitrogen, followed by either suspending in CTAB buffer at $65^{\circ} \mathrm{C}$ for 15 min with subsequent phenol/chloroform extraction (24), or boiling ground root tissue in Tris-EDTA buffer (14). These methods resulted in DNA suspensions containing a brown substance(s), which could be phenol or lignin (4). No DNA fragments were amplified when these substances were present. The only method effective in obtaining DNA suitable for PCR was the QIAGEN DNA extraction method. This procedure was efficient in removing the PCR inhibitors from plant tissue and was cost-effective when used for large numbers of samples ( U.S. \$1.50 per sample).

\section{LITERATURE CITED}

1. Apples, J. B., and Honeycutt, R. L. 1996. rDNA: Evolution over a billion years. Pages 81-135 in: DNA Systematics. Vol. 2. S. K. Dutter, ed. CRC Press, Boca Raton, FL.

2. Bryan, G. T., Daniels, M. J., and Osbourn, A. E. 1995. Comparison of fungi within the Gaeumannomyces-Phialophora complex by analysis of ribosomal DNA sequences. Appl. Environ. Microbiol. 61:681-689.

3. Bunting, T. E., Plumley, K. A., Clarke, B. B., and Hillman, B. I. 1996. Identification of Magnaporthe poae by PCR and examination of its relationship to other fungi by analysis of their nuclear rDNA ITS-1 regions. Phytopathology 86:398-404.

4. Chen, W., Gray, L. E., and Grau, C. R. 1996. Molecular differentiation of fungi associated with brown stem rot and detection of Phialophora gregata in resistant and susceptible soybean cultivars. Phytopathology 86:11401148.

5. Elliott, M. L. 1991. Determination of an etiological agent of Bermudagrass decline. Phytopathology 81:1380-1384.

6. Elliott, M. L., Hagan, A. K., and Mullen, J. M. 1993. Association of Gaeumannomyces graminis var. graminis with a St. Augustinegrass root rot disease. Plant Dis. 77:206-209.

7. Elliott, M. L., and Landschoot, P. J. 1991. Fungi similar to Gaeumannomyces associated with root rot of turfgrasses in Florida. Plant Dis. 75:238-241.

8. Fouly, H. M., Wilkinson, H. T., and Chen, W. 1997. Restriction analysis of internal transcribed spacers and the small subunit gene of ribosomal DNA among four Gaeumannomyces species. Mycologia 89:590-597.

9. Gill, H. S., and Zentmeyer, G. A. 1978. Identification of Phytophthora species by disc electrophoresis. Phytopathology 68:163-167.

10. Henson, J. M., Goins, T., Grey, W., Mathre, D. E., and Elliott, M. L. 1993. Use of polymerase chain reaction to detect Gaeumannomyces graminis DNA in plants grown in artificially and naturally infested soil. Phytopathology 83:283-287.

11. Higgins, D. G., Bleasby, A. J., and Fuchs, R. 1992. CLUSTAL V: Improved software for multiple sequence alignment. Comput. Appl. Biosci. 8:189-191.

12. Hori, H., and Osawa, S. 1987. Origin and evaluation of organisms as deduced from $5 \mathrm{~S}$ ribosomal RNA sequences. Mol. Biol. Evol. 4:445-472.

13. Krausz, J. P. 1991. Take-all patch suspected in Texas warm-season turf. South. Turf Managmt. 2:12.

14. Mazzola, M., Wong, O. T., and Cook, R. J. 1996. Virulence of Rhizoctonia oryzae and $R$. solani AG-8 on wheat and detection of $R$. oryzae in plant tissues by PCR. Phytopathology 86:354-360.

15. McCarty, L. B., and Lucas, L. T. 1989. Gaeumannomyces graminis associated with spring dead spot of Bermudagrass in the southeastern United States. Plant Dis. 73:659-661.

16. Moukhamedov, R., Hu, X., Nazar, R. N., and Robb, J. 1994. Use of polymerase chain reaction-amplified ribosomal intergenic sequences for the diagnosis of Verticillium tricorpus. Phytopathology 84:256-259.
17. Murray, M. G., and Thompson, W. F. 1980 Rapid isolation of high molecular weight plant DNA. Nucleic Acids Res. 8:43214325.

18. Nazar, R. N., Hu, X., Schmidt, J., Culham, D., and Robb, J. 1991. Potential use of PCR-amplified ribosomal intergenic sequences in the detection and differentiation of Verticillium wilt pathogens. Physiol. Mol. Plant Pathol. 39:1-11.

19. Qu, T. H., Michot, B., and Bachellerie, J. P. 1983. Improved methods for structure probing in large RNAs: A rapid "heterologous" sequencing approach is coupled to the direct mapping of nuclease accessible sites. Application to the $5^{\prime}$ terminal domain of eukaryotic 28S rRNA. Nucleic Acids Res. 11:5903-5920.

20. Qu, T. H., Nicoloso, M., and Bachellerie, J. P 1988. Phylogenetic calibration of the $5^{\prime}$ terminal domain of large rRNA achieved by determining twenty eukaryotic sequences. J. Mol. Evol. 28:113-124.

21. Schesser, K., Luder, A., and Henson, J. M. 1991. Use of polymerase chain reaction to detect the take-all fungus, Gaeumannomyces graminis, in infected wheat plants. Appl. Environ. Microbiol. 57:553-556.

22. Schilling, A. G., Moller, E. M., and Geiger, H. H. 1996. Polymerase chain reaction-based assay for species-specific detection of Fusarium culmorum, $F$. graminearum, and $F$. avenaceum. Phytopathology 86:515-522.

23. Smiley, R. W., Dernoeden, P. H., and Clarke, B. B. 1992. Compendium of Turfgrass Diseases. 2nd ed. American Phytopathological Society, St. Paul, MN.

24. Tisserat, N. A., Hulbert, S. H., and Sauer, K. M. 1994. Selective amplification of rDNA internal transcribed spacer regions to detect Ophiosphaerella korrae and O. herpotricha. Phytopathology 84:478-482.

25. Walker, J. 1980. Gaeumannomyces, Linocarpon, Ophiobolus, and several other genera of scolecospored Ascomycetes and Phialophora conidial states, with a note on hyphopodia. Mycotaxon 11:1-129.

26. Walker, J. 1981. Taxonomy of take-all fungi and related genera and species. Pages 15-74 in: Biology and Control of Take-all. M. J. C. Asher and P. J. Shipton, eds. Academic Press, London, UK

27. White, T. J., Bruns, T., Lee, S., and Taylor, J. 1990. Amplification and direct sequencing of fungal ribosomal RNA genes for phylogenetics. Pages 315-322 in: PCR Protocols, A Guide to Methods and Applications. M. A. Innis, D. H. Gelfand, J. J. Sninsky, and T. J. White, eds. Academic Press, San Diego.

28. Wilkinson, H. T. 1994. Root rot of centipedegrass (Eremochloa ophiuroides (Munro) Hack.) caused by Gaeumannomyces graminis ((Sacc.) Arx \& Olivier) var. graminis. Plant Dis. 78:1220.

29. Wilkinson, H. T., Cook, R. J., and Alldredge, J. R. 1985. Relation of inoculum size and concentration to infection of wheat roots by Gaeumannomyces graminis var. tritici. Phytopathology 75:98-103.

30. Wilkinson, H. T., and Kane, R. T. 1993. Gaeumannomyces graminis infecting zoysiagrass in Illinois. Plant Dis. 77:100.

31. Wilkinson, H. T., and Pedersen, D. 1993. Gaeumannomyces graminis var. graminis infecting St. Augustinegrass in southern California. Plant Dis. 77:536.

32. Woese, C. R., Stackebrandt, E., Macke, T. J., and Fox, G. E. 1985. Phylogenetic definition of the major eubacteria taxa. Syst. Appl. Microbiol. 6:143-151. 